\title{
Trophic upgrading of picocyanobacterial carbon by ciliates for nutrition of Daphnia magna
}

\author{
Dominik Martin-Creuzburg ${ }^{1,2, *}$, Alexandre Bec $^{1,3}$, Eric von Elert $^{1}$ \\ ${ }^{1}$ Limnological Institute, Mainaustrasse 252, University of Konstanz, 78464 Konstanz, Germany \\ ${ }^{2}$ Present address: Department of Animal Ecology I, Universitätsstrasse 30, University of Bayreuth, 95440 Bayreuth, Germany \\ ${ }^{3}$ Present address: Laboratoire de Biologie des Protistes, UMR CNRS 6023, Université Blaise Pascal, 63177 Aubiere cedex, France
}

\begin{abstract}
Unicellular picocyanobacteria, such as species of the genus Synechococcus, are unsuitable for supporting growth and reproduction of Daphnia spp. In Synechococcus spp., long-chain polyunsaturated fatty acids (PUFAs) and sterols are absent, which leads to a low carbon transfer efficiency at the picocyanobacteria-Daphnia spp. interface. Herein, we address the question as to whether ciliates can serve as a trophic link between picocyanobacterial production and Daphnia spp. production, thereby upgrading the nutritional value of a picocyanobacterial food source by producing essential lipids such as PUFAs or sterols. In simplified experimental food chains consisting of 1 of 2 different Synechococcus strains, the ciliates Colpidium campylum or Cyclidium sp., and D. magna, we provided evidence that predation on ciliates by Daphnia spp. allows access to picocyanobacterial production. Since daphnids are primarily sterol-limited when grown on the picocyanobacteria Synechococcus spp., the observed trophic upgrading of Synechococcus food-quality by intermediary ciliates is most probably due to the addition of sterols or sterol-like compounds that (at least partly) release Daphnia spp. from sterol limitation. The absence of sterols in the ciliates used in the present study suggests that tetrahymanol and/or hopanoids provide functional equivalents of sterols not only in ciliates but also in Daphnia spp., thereby leading to enhanced growth of the cladocerans.
\end{abstract}

KEY WORDS: Synechococcus spp. · Colpidium campylum $\cdot$ Cyclidium spp. $\cdot$ Sterols $\cdot$ Tetrahymanol · Hopanoids

Resale or republication not permitted without written consent of the publisher

\section{INTRODUCTION}

The significance of autotrophic picoplankton (APP) for primary production in aquatic ecosystems has often been recognized. Unicellular picocyanobacteria are the major constituents of APP; they often dominate both the total phytoplankton biomass and the production in oligotrophic to mesotrophic lakes (Weisse 1993, Callieri \& Stockner 2002). Numerous planktonic organisms are able to feed on picoplankton-sized particles. Heterotrophic nanoflagellates and nanociliates are considered to be the most important APP grazers (Sanders et al. 1989, Weisse et al. 1990, Šimek et al. 1995, Pernthaler et al. 1996), and themselves contribute significantly to zooplankton nutrition, thus transferring energy via the microbial loop to higher trophic levels (Stoecker \& Capuzzo 1990). However, the importance of protozoans for carbon-transfer efficiency in aquatic food webs is controversial. By repackaging their prey into accessible particles, protozoans are often implicated as a 'trophic link' to metazoan grazers (Gifford 1991). Copepods prey inefficiently on small particles $(<5 \mu \mathrm{m})$ so that an intermediate protozoan level might give access to APP production that otherwise would not be available for higher trophic levels (Jack \& Gilbert 1993). In contrast, both APP and most protozoans fall within the prey size spectrum of the aquatic keystone species of the genus Daphnia (Jürgens 1994) and, therefore, an intermediate trophic level can also be considered as a 'sink' of energy, since the efficiency with which carbon is transferred to higher trophic levels depends mainly on the 
number of trophic steps through which it has to pass (Pomeroy \& Wiebe 1988). However, picocyanobacteria, such as species of the genus Synechococcus, are unsuitable for supporting Daphnia spp. growth and reproduction (Lampert 1977a,b, 1981, Von Elert et al. 2003, Martin-Creuzburg \& Von Elert 2004, MartinCreuzburg et al. 2005); therefore, cladocerans might also benefit from grazing on protozoans, provided that protozoan carbon is more suitable for Daphnia spp.

In the genus Synechococcus, long-chain polyunsaturated fatty acids (PUFAs) and sterols are absent, which has led to the hypothesis that the low carbon-transfer efficiency at the cyanobacteria-Daphnia spp. interface is caused by the lack of either of these essential lipid classes (DeMott \& Müller-Navarra 1997, Von Elert \& Wolffrom 2001, Von Elert et al. 2003). Therefore, the role of protozoans as intermediary grazers might not be restricted to channelling energy; they might also upgrade the biochemical composition of food deficient in essential lipids by producing PUFAs or sterols (Klein Breteler et al. 1999, Bec et al. 2003b, Tang \& Taal 2005).

Ciliates are abundant protists in freshwater ecosytems (Pace \& Orcutt 1981, Beaver \& Crisman 1982, Pace 1982, Porter et al. 1985, Müller 1989). Reports from laboratory (Tezuka 1974, Porter et al. 1979, Sanders et al. 1996) and field (Carrick et al. 1991, Pace \& Funke 1991, Marchessault \& Mazumder 1997, Jürgens et al. 1999, Zöllner et al. 2003) experiments have revealed that cladocerans are important ciliate predators. However, investigations of food-quality aspects of ciliates in Daphnia spp. nutrition are scarce. Available data suggest that, although rich in nitrogen and phosporus, ciliates are less nutritious for daphnids than many algae (DeBiase et al. 1990, Sanders et al. 1996, Bec et al. 2003a). The fatty acid composition of ciliates seems to be highly diverse and points to speciesspecific differences in their capacity to synthesize PUFAs potentially important for zooplankton growth (Kaneshiro et al. 1979, Desvilettes et al. 1997, Sul et al. 2000, Klein Breteler et al. 2004). Although ciliates presumably lack the ability to synthesize sterols de novo, exogenously supplied sterols can be incorporated into cell membranes and metabolized into various other sterols (Conner et al. 1968, Harvey \& McManus 1991, Harvey et al. 1997). In the absence of exogenous sterols, the pentacyclic triterpenoid alcohol tetrahymanol is produced; tetrahymanol is functionally equivalent to sterols as a structural component of cell membranes in ciliates (Conner et al. 1968). Ederington et al. (1995) reported the assimilation of tetrahymanol in copepod tissues when ciliates were offered as food, but the possible effects of tetrahymanol on the growth and reproduction of zooplankton with regard to sterol limitation have not yet been identified.
In the present study, we investigated the potential of ciliates to serve as a trophic link between Synechococcus spp. and zooplankton production. In experimental tritrophic food chains consisting of 1 of 2 different Synechococcus strains, the ciliates Colpidium campylum or Cyclidium sp., and Daphnia magna, we tested the ability of ciliates as intermediary grazers to upgrade the food quality of cyanobacterial APP for $D$. magna, by producing essential lipids such as PUFAs or sterols.

\section{MATERIALS AND METHODS}

Cultivation of cyanobacteria and algae. The green alga Scenedesmus obliquus (SAG 276-3a; Sammlung von Algenkulturen Göttingen, Germany) was used as food for stock cultures of Daphnia magna; it was grown in batch cultures in Cyano medium (Jüttner et al. 1983) at $20^{\circ} \mathrm{C}$ with illumination at $120 \mu \mathrm{mol}$ quanta $\mathrm{m}^{-2} \mathrm{~s}^{-1}$, and harvested in the late-exponential phase. The coccoid cyanobacteria Synechococcus elongatus (SAG 89.79) and Synechococcus sp. Strain BO8809 (isolated from Lake Constance by A. Ernst in 1988: for detailed information see Ernst et al. 1991) were each grown in Cyano medium at $20^{\circ} \mathrm{C}$ with illumination at $60 \mu \mathrm{mol}$ quanta $\mathrm{m}^{-2} \mathrm{~s}^{-1}$. The flagellate Cryptomonas $\mathrm{sp}$. (SAG 26.80) was grown in modified Woods Hole (WC) medium containing vitamins (Guillard 1975) at $20^{\circ} \mathrm{C}$ with illumination at $120 \mu \mathrm{mol}$ quanta $\mathrm{m}^{-2} \mathrm{~s}^{-1}$. The cyanobacteria and Cryptomonas sp. were cultured semi-continuously at a dilution rate of $0.25 \mathrm{~d}^{-1}$ in aerated 51 vessels. Stock solutions of these organisms for the growth experiments were prepared by concentrating the cells by centrifugation and resuspension in WC medium lacking vitamins. Carbon concentrations of the food suspensions were estimated from photometric light extinction $(800 \mathrm{~nm})$ and from carbon-extinction equations determined previously.

Cultivation of protozoans. Colpidium campylum was obtained from the Laboratoire de Biologie des Protistes (Université Blaise Pascal, France) and Cyclidium sp. was obtained from the culture collection of the Limnological Institute (University of Konstanz, Germany). The protozoans were cultivated semi-continuously at $20^{\circ} \mathrm{C}$ in mineral water $\left(\right.$ Volvic $^{\circledR}$ ). Ciliates were fed with 1 of the 2 Synechococcus strains at approximately $2 \mathrm{mg}$ $\mathrm{C}^{-1}$ and, in order to maintain exponential growth, 20 to $40 \%$ of the medium was renewed every other day.

For the growth experiments, ciliate cells were separated from their food source by repeated centrifugation (1600 to $1900 \times g, 3$ to $5 \mathrm{~min}$, for Colpidium campylum; 2000 to $2300 \times g, 3$ to $5 \mathrm{~min}$, for Cyclidium sp.) and resuspension in fresh medium, taking advantage of their negative geotaxis. Subsequently, the ciliate sus- 
pensions were slowly filtered through a $12 \mu \mathrm{m}$ (Colpidium campylum) or $5 \mu \mathrm{m}$ (Cyclidium sp.) membrane filter without vacuum, and cells retained on the filter were immediately resuspended in mineral water to obtain protist stock suspensions. Subsamples of the stock suspensions were taken to estimate the number of cells in the food suspensions using a SedgewickRafter chamber. Cell sizes were determined by measuring the length and width of at least 50 unpreserved cells using an image-analysis system (see Table 1); the cell volume was computed using the geometric formula of a prolate spheroid (Hillebrand et al. 1999). To estimate the contamination of the Daphnia maga food suspension with Synechococcus spp., subsamples were DAPI-stained and enumerated by epifluorescence microscopy. In the ciliate suspensions used to feed D. magna, Synechococcus spp. comprised $<30 \%$ of the total carbon. Ciliate suspensions used for analysis were prepared separately and more thoroughly, leading to a contamination of $<15 \%$ of the total carbon. Contamination with bacteria was negligible in all treatments $(<0.6 \%$ of total carbon; bacterial carbon was estimated according to Bratbak 1985).

Daphnia magna growth experiments. Growth experiments were conducted with third-clutch juveniles (born within $10 \mathrm{~h}$ ) of a clone of D. magna originally isolated from Großer Binnensee, Germany (Lampert 1991). The experiments were carried out at $20^{\circ} \mathrm{C}$ in glass beakers filled with $200 \mathrm{ml}$ of filtered lake water ( $0.45 \mu \mathrm{m}$ pore-sized membrane filter). Each treatment consisted of 3 replicates with 7 daphnids each. The food suspensions, containing $1.5 \mathrm{mg} \mathrm{C}^{-1}$ of Synechococcus spp. or Cryptomonas sp. $\left(1.4 \times 10^{4}\right.$ cells ml $\left.^{-1}\right)$ and $1 \mathrm{mg} \mathrm{Cl}^{-1}\left(9 \times 10^{2}\right.$ Colpidium campylum $\mathrm{ml}^{-1} ; 1 \times$ $10^{4}$ Cyclidium sp. $\mathrm{ml}^{-1}$ ) of ciliate biomass, were renewed daily during the $6 \mathrm{~d}$ experiments. Somatic growth rates $(g)$ were determined as the increase in dry weight $(W)$ during the experiments using:

$$
g=\left(\ln W_{t}-\ln W_{0}\right) / t
$$

Subsamples of the experimental daphnids consisting of 7 individuals were taken at the beginning $\left(W_{0}\right)$ and at the end $\left(W_{t}\right)$ of an experiment, where $t$ is the duration of the experiments $(6 \mathrm{~d})$. After $24 \mathrm{~h}$ in a drying chamber, subsamples were weighed on an electronic balance (Mettler UMT $2 ; \pm 0.1 \mu \mathrm{g}$ ). Growth rates were calculated as means for each treatment.

Chemical analysis. For the analysis of fatty acids and neutral lipids (sterols and sterol-like compounds, e.g. tetrahymanol), $0.5 \mathrm{mg}$ particulate organic carbon (POC) of the food suspensions was filtered on precombusted GF/F filters (Whatman, $25 \mathrm{~mm}$ diameter). Total lipids were extracted 3 times from filters with dichloromethane/methanol $(2: 1, \mathrm{v} / \mathrm{v})$, and the pooled cell-free extracts were evaporated to dryness with nitrogen. The lipid extracts were transesterified with 3 mol methanolic $\mathrm{HCl}^{-1}\left(60^{\circ} \mathrm{C}, 15 \mathrm{~min}\right)$ for the analysis of fatty acids or saponified with $0.2 \mathrm{~mol}$ methanolic $\mathrm{KOH} ~^{-1}\left(70^{\circ} \mathrm{C}, 1 \mathrm{~h}\right)$ for the analysis of sterols. Subsequently, fatty acid methyl esters (FAMEs) were extracted 3 times with $2 \mathrm{ml}$ iso-hexane; neutral lipids were partitioned into iso-hexane:diethyl ether (9:1, $\mathrm{v} / \mathrm{v})$. The lipid-containing fraction was evaporated to dryness under nitrogen and resuspended in 10 to $20 \mu \mathrm{l}$ iso-hexane.

Lipids were analyzed by gas chromatography on an HP 6890 GC equipped with a flame ionization detector and either a DB-225 (J\&W Scientific) capillary column to analyze FAMEs or an HP-5 (Agilent) capillary column to analyze sterols. Details of GC configurations are given elsewhere (Von Elert 2002 for fatty acids, Martin-Creuzburg \& Von Elert 2004 for sterols). Lipids were quantified by comparison to internal standards (C17:0 and C23:0 methyl esters; $5 \alpha$-cholestan) and identified by their retention times and their mass spectra, which were recorded with a gas chromatograph/mass spectrometer (Finnigan MAT GCQ) equipped with a fused-silica capillary column (DB225MS, J\&W Scientific for FAMEs; DB-5MS, Agilent for sterols). Sterols and sterol-like compounds were analyzed in their free form and as their trimethylsilyl derivatives. Spectra were recorded between 50 and 600 atomic mass units in the EI ionization mode. Mass spectra were identified by comparison with mass spectra of reference substances (e.g. tetrahymanol and diplopterol, provided by M. Rohmer) or spectra found in a self-generated spectra library or in the literature (e.g. Ten Haven et al. 1989, Venkatesan 1989, Harvey \& McManus 1991). The detection limit was $20 \mathrm{ng}$ of fatty acid or sterol. It was not possible to distinguish between petroselinic acid $(\mathrm{C} 18: 1 \mathrm{n}-12)$ and oleic acid (C18:1n-9). The absolute amount of each lipid was related to the POC. Therefore, aliquots of the food suspensions were filtered onto precombusted glass-fiber filters (Whatman GF/F, $25 \mathrm{~mm}$ diameter) and analyzed for POC and nitrogen using an NCS2500 analyzer (ThermoQuest). For determination of particulate phosphorus, aliquots were collected on acid-rinsed polysulfon filters (HT-200; Pall) and digested with a solution of $10 \%$ potassium peroxodisulfate and $1.5 \%$ sodium hydroxide for $60 \mathrm{~min}$ at $121^{\circ} \mathrm{C}$, and soluble reactive phosphorus was determined using the molybdate-ascorbic acid method (Greenberg et al. 1985).

Data analysis. The somatic growth rates of Daphnia magna were analyzed using 1-way analysis of variance (ANOVA). Raw data met the assumption of homogeneity of variance (Levene's test); single-treatment effects were tested by Tukey's HSD post-hoc test $(\mathrm{p}=0.05)$. 


\section{RESULTS}

Microscopy revealed high grazing activities of both ciliate species on the 2 Synechococcus strains. The red cells of Synechococcus sp. Strain BO8809 and the green cells of $S$. elongatus could easily be observed in the food vacuoles of the ciliates.

The 2 ciliate species differed significantly in size (Table 1), but cell sizes were not affected by the food source of the ciliates. The cell sizes of Cryptomonas sp. and Cyclidium sp. were similar.

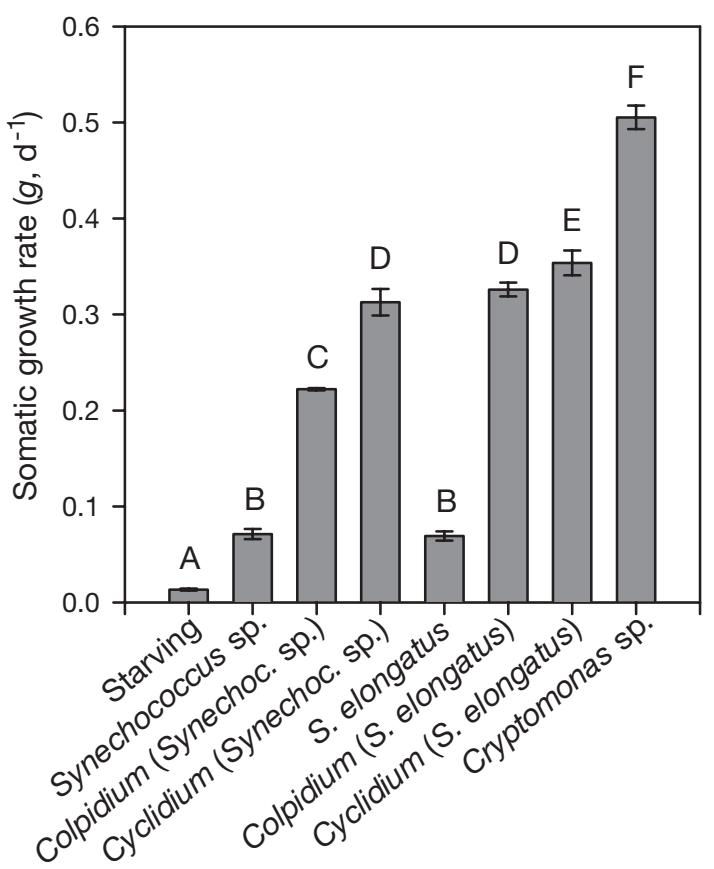

Fig. 1. Daphnia magna. Mean $\pm \mathrm{SD}(\mathrm{n}=3)$ juvenile somatic growth rates of daphnids grown on Synechococcus sp. Strain BO8809, S. elongatus, or ciliates previously fed 1 of the 2 Synechococcus strains (given in parentheses). Growth without food supply ('Starving') and growth on flagellate Cryptomonas sp. are shown for comparison. Bars labelled with same letter are not significantly different (Tukey's HSD, $p<0.05$ following ANOVA)

\section{Growth experiments}

Juvenile somatic growth rates ( $g$ ) of Daphnia magna were significantly affected by the food supplied in the growth experiments (ANOVA, $F_{7,16}=1146 ; \mathrm{p}<0.001$; Fig. 1). Growth rates of D. magna ranged from $0.01 \mathrm{~d}^{-1}$ without food supply to $0.51 \mathrm{~d}^{-1}$ when fed on Cryptomonas sp. The cyanobacteria Synechococcus sp. Strain BO8809 and S. elongatus did not differ in their food quality for $D$. magna (Tukey's HSD, $\mathrm{p}=1$ ); growth on both strains was in general poor $\left(g=0.07 \mathrm{~d}^{-1}\right)$. In comparison to growth on pure Synechococcus spp., D. magna exhibited significantly higher growth rates on ciliates fed either of the 2 Synechococcus strains. Growth of $D$. magna was significantly higher on either of the ciliates fed on $S$. elongatus than on either of the ciliates fed on Synechococcus sp. Strain BO8809 (Tukey's HSD, p < 0.05). Regardless of the food source of the ciliates, Cyclidium sp. improved the growth of $D$. magna more than Colpidium campylum (Tukey's HSD, p < 0.05).

\section{Elemental nutrient ratios}

The carbon:nitrogen $(\mathrm{C}: \mathrm{N})$ and carbon:phosphorus (C:P) ratios of the various food suspensions are given in Table 2. The 2 Synechococcus strains were characterized by high nitrogen and phosphorus content; however, the C:N and C:P ratios were slightly lower in Synechococcus sp. Strain BO8809 than in S. elongatus. The C:N ratios of ciliates ranged from 4.40 to 4.92 . The C:P ratios were in general lower in Colpidium campylum than in Cyclidium sp. The nutrient ratios of the ciliates seemed to be affected by the nutrient ratios of their food source: the $\mathrm{C}: \mathrm{N}$ and C:P ratios tended to be lower when the nitrogen- and phosphorus-rich Synechococcus sp. Strain BO8809 was offered as food. The nitrogen content of the flagellate Cryptomonas sp. was lower (higher C:N ratio) than that of the ciliates, whereas the $\mathrm{C}: \mathrm{P}$ ratio was comparable to that of Cyclidium sp.

Table 1. Colpidium campylum and Cyclidium sp. Cell sizes of ciliates grown on 1 of 2 different Synechococcus strains (Synechococcus sp. = Strain BO8809) and cell size of flagellate Cryptomonas sp. ( $\mathrm{n}=50$ for all species)

\begin{tabular}{|c|c|c|c|c|c|c|c|}
\hline \multirow{2}{*}{ Species } & \multicolumn{3}{|c|}{ Length $(\mu \mathrm{m})$} & \multicolumn{3}{|c|}{ Width $(\mu \mathrm{m})$} & \multirow{2}{*}{$\begin{array}{c}\text { Vol. }\left(\mu \mathrm{m}^{3}\right. \\
\text { Mean }\end{array}$} \\
\hline & Mean $\pm \mathrm{SD}$ & Max. & Min. & Mean $\pm \mathrm{SD}$ & Max. & Min. & \\
\hline \multicolumn{8}{|c|}{ Colpidium campylum fed: } \\
\hline Synechococcus sp. & $43.9 \pm 3.9$ & 52.3 & 36.2 & $20.0 \pm 2.4$ & 24.3 & 14.9 & 9164.7 \\
\hline S. elongatus & $44.4 \pm 4.2$ & 52.5 & 27.2 & $20.0 \pm 2.7$ & 25.8 & 12.1 & 9301.2 \\
\hline \multicolumn{8}{|l|}{ Cyclidium sp. fed: } \\
\hline Synechococcus sp. & $18.0 \pm 2.1$ & 22.3 & 12.4 & $8.9 \pm 1.5$ & 15.7 & 6.6 & 739.9 \\
\hline S. elongatus & $17.8 \pm 2.2$ & 22.2 & 10.4 & $8.1 \pm 1.1$ & 11.3 & 5.6 & 611.8 \\
\hline Cryptomonas sp. & $19.1 \pm 1.7$ & 23.1 & 15.0 & $8.8 \pm 1.1$ & 11.4 & 7.0 & 778.3 \\
\hline
\end{tabular}




\section{Sterols and sterol-like compounds}

Sterols were not detected in the 2 Synechococcus strains or in the 2 ciliate species. Neutral lipids of $\mathrm{Col}$ pidium campylum were characterized by the triter-

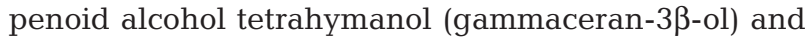
its hopanoid isomer diplopterol. In Cyclidium sp., tetrahymanol was accompanied by hopan-3 $\beta$-ol (Table 3). Stigmasterol (24-ethylcholesta-5,22-dien$3 \beta$-ol) and epibrassicasterol (24-methylcholesta-5,22dien-3 $\beta$-ol) were the principal sterols found in Cryptomonas sp. Epibrassicasterol, the $24 \alpha$-epimer of brassicasterol, occurs in cryptophycean algae, such as species of Cryptomonas and Rhodomonas (Goad et al. 1983, Gladu et al. 1990). Although we did not determine the stereochemistry of the side chain at C-24, a $24 \alpha$-configuration was also assumed.

\section{Fatty acids}

PUFAs were not detected in either Synechococcus strain, except for low amounts of 16:2n-6 in both strains and traces of 16:2n-4 in Synechococcus sp. Strain BO8809 (Fig. 2). Instead, both strains were characterized by high amounts of short-chain saturated fatty acids and the monounsaturated fatty acid 16:1n-7.

Table 2. Mean $\pm \mathrm{SD}(\mathrm{n}=3)$ carbon:nitrogen $(\mathrm{C}: \mathrm{N})$ and carbon:phosphorus (C:P) molar ratios of different food suspensions offered to Daphnia magna. Synechococcus sp. = Strain BO8809

\begin{tabular}{|lcr|}
\hline Food & C:N & \multicolumn{1}{c|}{ C:P } \\
\hline Synechococcus sp. & $2.89 \pm 0.62$ & $79.87 \pm 34.39$ \\
S. elongatus & $4.46 \pm 0.03$ & $156.29 \pm 12.13$ \\
Colpidium campylum fed: & & \\
$\quad$ Synechococcus sp. & $4.40 \pm 0.16$ & $58.78 \pm 2.78$ \\
$\quad$ S. elongatus & $4.73 \pm 0.03$ & $71.79 \pm 3.61$ \\
Cyclidium sp. fed: & & \\
$\quad$ Synechococcus sp. & $4.80 \pm 0.08$ & $113.19 \pm 3.92$ \\
S. elongatus & $4.92 \pm 0.35$ & $161.96 \pm 3.73$ \\
Cryptomonas sp. & $5.49 \pm 0.07$ & $123.95 \pm 6.14$ \\
\hline
\end{tabular}

Compared to the fatty acid composition of the cyanobacteria, Colpidium campylum contained high amounts of n-6 PUFAs such as 16:2n-6, 18:2n-6, and 18:3n-6, and, in addition, moderate amounts of $16: 2 \mathrm{n}$ 4, 16:3n-4, 18:1n-7, and 18:2n-7. In contrast, Cyclidium sp. was characterized by high amounts of n-3 PUFAs (18:3n-3, 18:4n-3) rather than n-6 PUFAs (Fig. 2). Dietary effects on the fatty acid content of the ciliates were negligible. The fatty acid composition of Cryptomonas sp. was dominated by high amounts of $\mathrm{n}-3$ PUFAs, such as 18:3n-3, 18:4n-3, and 20:5n-3. The total fatty acid content was highest in Cryptomonas sp. $\left(211.0 \pm 12.6 \mu \mathrm{g} \mathrm{mg}^{-1} \mathrm{C}\right)$ and lowest in the Synechococcus strains $\left(79.3 \pm 4.9 \mathrm{\mu g} \mathrm{mg}^{-1} \mathrm{C}\right.$ in Synechococcus sp. Strain BO8809; $98.8 \pm 4.6 \mu \mathrm{g} \mathrm{mg}^{-1} \mathrm{C}$ in $S$. elongatus). The ciliates showed intermediate contents of total fatty acids: $121.7 \pm 2.3 \mu \mathrm{g} \mathrm{mg}^{-1} \mathrm{C}$ in Colpidium campylum fed on Synechococcus sp. Strain BO8809; $112.0 \pm$ $4.7 \mu \mathrm{g} \mathrm{mg}^{-1} \mathrm{C}$ in C. campylum fed on S. elongatus; $131.7 \pm 13.0 \mu \mathrm{g} \mathrm{mg}^{-1} \mathrm{C}$ in Cyclidium sp. fed on Synechococcus sp. strain BO8809; and $161.4 \pm 18.4 \mathrm{\mu g} \mathrm{mg}^{-1}$ $\mathrm{C}$ in Cyclidium sp. fed on $S$. elongatus.

\section{DISCUSSION}

In oligotrophic to mesotrophic lakes, picocyanobacteria, such as Synechococcus species, are abundant autotrophic prokaryotes that often contribute significantly to primary production, thereby forming the base of a complex pelagic food web (Weisse 1993, Callieri \& Stockner 2002). Grazing by ciliates can be considered as an important loss process controlling biomass and production of APP in freshwater ecosystems (Fahnenstiel et al. 1991, Sherr et al. 1991, Šimek et al. 1995, Hadas \& Berman 1998).

The 2 ciliate species Colpidium campylum and Cyclidium sp. used in the present study showed high grazing activities on both Synechococcus strains. Although bacterial contamination was marginal, the consumption of bacteria could not be excluded since none of the ciliate cultures was axenic. However, the importance of picocyanobacteria as a potential carbon source for ciliates (e.g. Cyclidium sp.) has already been

Table 3. Colpidium campylum and Cyclidium sp. Mean \pm SD $(n=3)$ neutral lipid content of ciliates $\left(\mu g \mathrm{mg}^{-1} \mathrm{C}\right)$. nd: not detected (Synechococcus sp. $=$ Strain BO8809)

\begin{tabular}{|c|c|c|c|c|}
\hline \multirow[t]{2}{*}{ Lipid } & \multicolumn{2}{|c|}{ Colpidium campylum fed: } & \multicolumn{2}{|c|}{ Cyclidium sp. fed: } \\
\hline & Synechococcus sp. & S. elongatus & Synechococcus sp. & S. elongatus \\
\hline Tetrahymanol & $5.87 \pm 1.64$ & $8.41 \pm 1.51$ & $1.95 \pm 0.31$ & $2.73 \pm 0.32$ \\
\hline Diplopterol & $10.48 \pm 2.45$ & $12.99 \pm 2.39$ & nd & nd \\
\hline 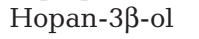 & nd & nd & $5.01 \pm 0.17$ & $5.28 \pm 0.23$ \\
\hline Total & $16.35 \pm 4.09$ & $21.40 \pm 3.90$ & $6.96 \pm 0.15$ & $8.01 \pm 0.51$ \\
\hline
\end{tabular}




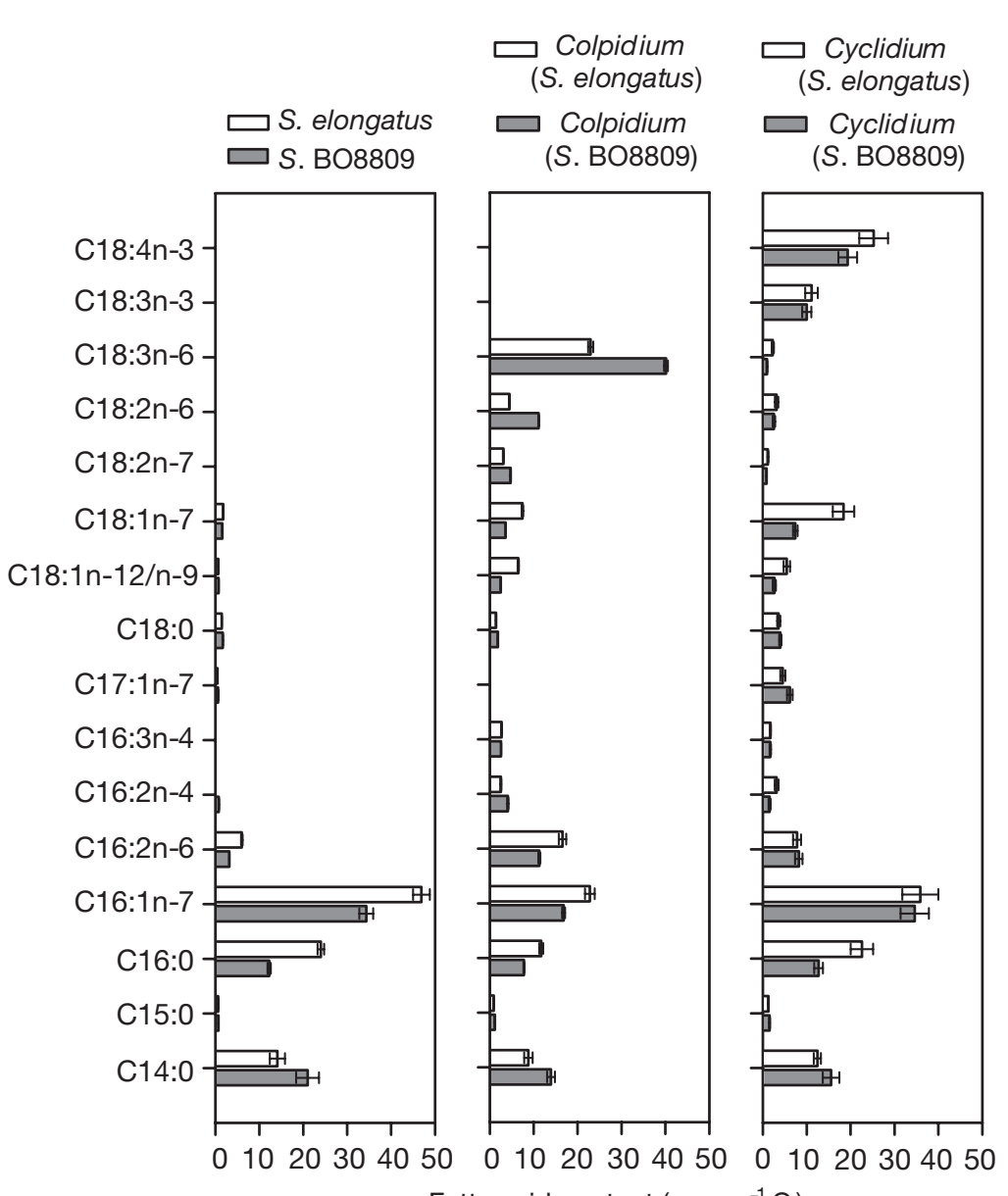

Fatty acid content $\left(\mu \mathrm{g} \mathrm{mg}{ }^{-1} \mathrm{C}\right)$

Fig. 2. Synechococcus sp. Strain BO8809 and S. elongatus, and Colpidium campylum and Cyclidium sp. previously fed either Synechococcus sp. Strain BO8809 or $S$. elongatus (given in parentheses). Mean $\pm \mathrm{SD}_{i}(\mathrm{n}=3)$ fatty acid content

demonstrated (Šimek et al. 1996), and, moreover, Šimek et al. (1996) reported a strong size selection towards larger picoplankton prey; therefore, the consumption of bacteria in the present study appears to have been negligible.

Invertebrate grazers, in particular cladocerans of the genus Daphnia, feed on a wide size-range of particles that includes picocyanobacteria and small ciliates (Jürgens 1994). It is well established that picocyanobacteria such as Synechococcus spp. are unsuitable for supporting growth of Daphnia spp. (Lampert 1977a,b, DeMott \& Müller-Navarra 1997, Von Elert et al. 2003, Martin-Creuzburg \& von Elert 2004, MartinCreuzburg et al. 2005), whereas effects of ciliates on Daphnia spp. nutrition are controversial. In the field, ciliates are suppressed during population peaks of Daphnia spp., and several experimental studies have shown that daphnids effectively prey on ciliates up to a certain size (Tezuka 1974, Porter et al. 1979, Jack \& Gilbert 1993, Sanders et al. 1996). However, ciliates are less nutritious for Daphnia spp. than many algae (DeBiase et al. 1990, Wickham et al. 1993, Sanders et al. 1996). In the present study, we addressed whether ciliates can serve as a trophic link between Synechococcus spp. production and Daphnia spp. production, thereby upgrading the nutritional value of a picocyanobacterial food source. Both Synechococcus strains used here were unsuitable as a sole food source for $D$. magna, whereas when either of the 2 ciliate species that fed on the Synechococcus strains was used as a food source, it significantly enhanced the somatic growth of the daphnid. The results of this simplified experimental food chain (Synechococcus spp. $\rightarrow$ ciliates $\rightarrow$ D. magna) suggest that predation on ciliates by Daphnia species allows access to picocyanobacterial production and provides a linkage of carbon flow to higher trophic levels. Moreover, ciliates obviously improve the quality of the supplied food by the addition of essential components that are absent in Synechococcus spp.

Synechococcus elongatus is a nontoxic picocyanobacterium that is assimilated well by Daphnia spp. (Lampert 1977a,b, 1981). The elemental nutrient ratios determined show that both Synechococcus strains and, possibly as a consequence, both ciliate species, were rich in phosphorus and nitrogen, which is in accordance with previous data (DeBiase et al. 1990, Sanders et al. 1996, DeMott 1998). In all treatments, C:P ratios were far below those determined for P-limited growth of Daphnia spp. (C:P > 300; Sterner \& Schulz 1998), and $\mathrm{C}: \mathrm{N}$ ratios were considerably lower than those usually found in phytoplankton species (e.g. Cryptomonas sp. in the present study). Thus, the growthenhancing trophic upgrading effect is unlikely to be due to the elemental nutrient supply.

Stoecker \& Capuzzo (1990) proposed that ciliates might be an important source of essential lipids, thus representing a supplementary diet to enhance growth of Daphnia spp. The lack of sterols in Synechococcus spp. has recently been identified as the major food quality constraint in Daphnia species (Von Elert et al. 2003, Martin-Creuzburg et al. 2005), which implies that the observed trophic upgrading of picocyanobacterial food quality by intermediary ciliates is due to the addition of sterols. However, available data suggest that ciliates lack the ability to synthesize sterols de novo (Conner et al. 1968, Harvey \& McManus 1991, 
Harvey et al. 1997, Klein Breteler et al. 2004). Instead, the pentacyclic triterpenoid alcohol tetrahymanol is produced, which is functionally equivalent to sterols as a structural component of cell membranes. Numerous studies have shown that exogenously supplied sterols can be incorporated into cell membranes of ciliates and, as a consequence, inhibit tetrahymanol synthesis (first demonstrated by Conner et al. 1968). Hence, the occurrence of sterols in ciliates depends on their diet: ciliates feeding on bacteria or picocyanobacteria cannot rely on a dietary source of sterols and, therefore, are expected to produce tetrahymanol. Sterols were not detected in either of the 2 ciliate species used in the present study; this lack of sterols can be attributed to the absence of sterols in their food source, Synechococcus spp. Instead, relatively high amounts of tetrahymanol and its isomer diplopterol were detected in Colpidium campylum; Cyclidium sp. contained considerably lower amounts of tetrahymanol and no diplopterol. Tetrahymanol was first identified in Tetrahymena pyriformis (Mallory et al. 1963), a ciliate related to $C$. campylum, but has recently also been observed in several marine scuticociliates, including Cyclidium sp. (Harvey \& McManus 1991). Neutral lipids of Cyclidium sp. were dominated by hopan-3 $\beta$ ol, a hopanoid that seems to be common among scuticociliates (Harvey \& McManus 1991, Harvey et al. 1997).

Like all arthropods, crustaceans are incapable of synthesizing sterols de novo and therefore must acquire these essential nutrients from their diet (Goad 1981). Daphnids feeding on bacterivorous or picocyanobacterivorous ciliates cannot rely on a dietary source of sterols and, therefore, are expected to be sterol limited. However, tetrahymanol and related compounds that functionally replace sterols as membrane reinforcers in ciliates (Raederstorff \& Rohmer 1988) might also be suitable as sterol surrogates in crustacean tissues. Thus, the observed trophic upgrading of Synechococcus spp. food quality by intermediary ciliates might be due to the addition of tetrahymanol and hopanoids, which at least partly release Daphnia spp. from sterol limitation. Ederington et al. (1995) reported the assimilation of tetrahymanol in tissues of ciliate-fed copepods (mainly in eggs) and suggested that tetrahymanol can provide functional equivalence to cholesterol, thereby maintaining minimal egg production. Beside their role as structural components of cell membranes, sterols serve as precursors for many bioactive molecules, such as ecdysteroids, which are involved in the process of molting (Goad 1981). Whether tetrahymanol and related compounds affect growth and/or reproduction of crustaceans remains to be tested, possibly by supplementation of a sterol-free diet with these compounds. Recently, for copepods, Klein Breteler et al. (2004) found no evidence for trophic upgrading of a sterol-deficient diet by the marine ciliate Strombidium sulcatum. However, neither sterols, tetrahymanol nor other sterol surrogates were detected in $S$. sulcatum, which possibly makes this bacterivorous ciliate unsuitable as a single food source for copepods, and corroborates the finding of this study that trophic upgrading of a sterol-free diet can be attributed to tetrahymanol-related compounds in ciliates.

Von Elert et al. (2003) have shown that when the shortage of sterols in Synechococcus spp. is overcome by supplementation with cholesterol, growth of Daphnia galeata is limited by the availability of long-chain PUFAs. Hence, the addition of PUFAs by the intermediary ciliates might have further improved the trophic upgrading effect, provided that the daphnids were released from sterol limitation.

Long-chain PUFAs were not detected in either of the Synechococcus strains. However, the fatty acid composition of Colpidium campylum was characterized by relatively high amounts of n-6 PUFAs (18:2n-6, 18:3n-6), which suggested a de novo synthesis of these fatty acids by $C$. campylum. This is corroborated by the finding that species of Tetrahymena synthesize n-6 PUFAs when grown on fatty-acid-free media (Sul \& Erwin 1997). In contrast, Cyclidium sp. synthesized high amounts of n-3 PUFAs (18:3n-3, 18:4n-3), which have previously been detected in marine scuticociliates: 18:3n-3 in Pleuronema sp. (Ederington et al. 1995), and 18:3n-3 and 18:4n-3 in Parauronema acutum (Sul \& Erwin 1997, Sul et al. 2000).

In most animals, the PUFAs 18:2n-6 and 18:3n-3 are essential dietary compounds that play important roles in animal physiology (Cook 1996). In Daphnia species, the n-6 PUFAs found in Colpidium campylum (18:2n-6, 18:3n-6) might be further converted into 20:4n-6, an intermediate in prostaglandin synthesis (Weers et al. 1997). However, laboratory experiments and correlative field studies suggest either $18: 3 n-3$ or $20: 5 n-3$ as a potentially limiting resource that constrains proper growth of Daphnia spp. (Müller-Navarra 1995, MüllerNavarra et al. 2000, Wacker \& Von Elert 2001, Von Elert 2002, Becker \& Boersma 2003, Ravet et al. 2003). In Cyclidium sp., comparatively high amounts of $\mathrm{n}-3$ PUFA (18:3n-3, 18:4n-3) were detected, which, in Daphnia spp., can be converted into 20:5n-3 through a process of elongation and desaturation. Although the conversion of 18:3n-3 into 20:5n-3 is low (Weers et al. 1997, Von Elert 2002), the availability of these PUFAs might be adequate to meet metabolic demands. Even though Cyclidium sp. contains less tetrahymanol and related compounds than Colpidium campylum, it resulted in a higher trophic upgrading of picocyanobacterial carbon, which leads to the conclusion that the amount of tetrahymanol-related compounds present in 
Cyclidium sp. was sufficient to release daphnids from the sterol limitation observed on pure Synechococcus spp. (Von Elert et al. 2003, Martin-Creuzburg et al. 2005). Hence, the superior quality of Cyclidium sp. must be attributed to compounds present in Cyclidium sp. but not in C. campylum. In accordance with the finding that when sterol requirements are met, growth of daphnids on Synechococcus spp. becomes limited by n-3 PUFAs (Von Elert et al. 2003), the synthesis of n3 PUFAs in Cyclidium sp. but not in Colpidium campylum provides a reasonable explanation for the superior food quality of the former.

Differences in the food quality of Colpidium campylum and Cyclidium sp. for Daphnia magna might also be due to their different cell sizes. Jack \& Gilbert (1993) reported that large ciliates are less susceptible to Daphnia spp. predation, and showed that clearance rates decrease with increasing ciliate size. C. campylum might be close to the upper size range of food particles that can be ingested as a whole by juvenile $D$. magna. Large particles up to a certain size have to be manipulated, which results in a reduced ingestion efficiency (Porter et al. 1979). However, ciliates much larger than $C$. campylum have been shown to be ingestible by $D$. pulex, and among various ciliates tested, a ciliate similar in size to C. campylum (Tetrahymena pyriformis) was most vulnerable to $D$. pulex predation (Jack \& Gilbert 1993). Therefore, it seems unlikely that the observed differences in food quality of the 2 ciliates derive exclusively from differences in cell sizes.

Although the ciliates used herein improved Synechococcus spp. food quality for Daphnia magna, growth rates achieved on a ciliate diet rank far below those achieved with the flagellate Cryptomonas sp., which contained comparatively high amounts of the $\Delta^{5}$ sterols stigmasterol and epibrassicasterol. $\Delta^{5}$ sterols such as stigmasterol have been shown to support somatic growth and reproduction of daphnids when used as supplements to the sterol- and PUFA-deficient S. elongatus (Martin-Creuzburg \& Von Elert 2004). In addition, the fatty acid composition of Cryptomonas sp. was dominated by high levels of $n-3$ PUFAs, especially 18:3n-3, 18:4n-3, and 20:5n-3, which is in accordance with previous data (e.g. Von Elert \& Stampfl 2000). This implies that the high food quality of Cryptomonas sp. is a combined effect of its sterol and PUFA composition.

In summary, the presented data clearly show that predation on ciliates by Daphnia magna (and presumably other species of this genus) can provide a linkage between picocyanobacterial production and zooplankton production. Especially in oligotrophic to mesotrophic lakes, where APP species often dominate phytoplankton assemblages, this might be an impor- tant pathway channelling carbon and essential nutrients to higher trophic levels. Daphnids have been shown to be primarily sterol-limited when grown on the picocyanobacteria Synechococcus spp., which implies that the observed trophic upgrading of APP food quality by intermediary ciliates is due to the addition of sterols or sterol-like compounds that (at least partly) release Daphnia spp. from sterol limitation. The absence of sterols in ciliates suggests that tetrahymanol and/or hopanoids are functional equivalents to sterols not only in ciliates but also in Daphnia spp., thereby leading to enhanced growth.

Acknowledgements. We thank P. Merkel and C. Gebauer for excellent technical assistance and M. Rohmer for providing us with standards of tetrahymanol and diplopterol. This work was supported by the German Research Foundation (DFG, EI 179/4-2), and by a post-doctoral fellowship to A.B. from the Conseil Régional d'Auvergne, France.

\section{LITERATURE CITED}

Beaver JR, Crisman TL (1982) The trophic response of ciliated protozoans in freshwater lakes. Limnol Oceanogr 27: 246-253

Bec A, Desvilettes C, Véra A, Fontvieille D, Bourdier G (2003a) Nutritional value of different food sources for the benthic Daphnidae Simocephalus vetulus: role of fatty acids. Arch Hydrobiol 156:145-163

Bec A, Desvilettes C, Véra A, Lemarchand C, Fontvieille D, Bourdier G (2003b) Nutritional quality of a freshwater heterotrophic flagellate: trophic upgrading of its microalgal diet for Daphnia hyalina. Aquat Microb Ecol 32:203-207

Becker C, Boersma M (2003) Resource quality effects on life histories of Daphnia. Limnol Oceanogr 48:700-706

Bratbak G (1985) Bacterial biovolume and biomass estimations. Appl Environ Microbiol 49:1488-1493

Callieri C, Stockner JG (2002) Freshwater autotrophic picoplankton: a review. J Limnol 61:1-14

Carrick HJ, Fahnenstiel GLF, Stoermer EF, Wetzel RG (1991) The importance of zooplankton-protozoan trophic couplings in Lake Michigan. Limnol Oceanogr 36:1335-1345

Conner RL, Landrey JR, Burns CH, Mallory FB (1968) Cholesterol inhibition of pentacyclic triterpenoid biosynthesis in Tetrahymena pyriformis. J Protozool 15:600-605

Cook HW (1996) Fatty acid desaturation and chain elongation in eukaryotes. In: Vance DE, Vance JE (eds) Biochemistry of lipids, lipoproteins and membranes. Elsevier Science, Amsterdam, p 129-152

DeBiase AE, Sanders RW, Porter KG (1990) Relative nutritional value of ciliate protozoa and algae as food for Daphnia. Microb Ecol 19:199-210

DeMott WR (1998) Utilization of a cyanobacterium and a phosphorus-deficient green alga as complementary resources by daphnids. Ecology 79:2463-2481

DeMott WR, Müller-Navarra DC (1997) The importance of highly unsaturated fatty acids in zooplankton nutrition: evidence from experiments with Daphnia, a cyanobacterium and lipids emulsions. Freshw Biol 38:649-664

Desvilettes C, Bourdier G, Amblard C, Barth B (1997) Use of fatty acids for the assessment of zooplankton grazing on bacteria, protozoans and microalgae. Freshw Biol 38: $629-637$ 
Ederington M, McManus GB, Harvey HR (1995) Trophic transfer of fatty acids, sterols, and a triterpenoid alcohol between bacteria, a ciliate, and the copepod Acartia tonsa. Limnol Oceanogr 40:860-867

Ernst A, Sandmann G, Postius C, Brass S, Kenter U, Böger P (1991) Cyanobacterial picoplankton from Lake Constance. II. Classification of isolates by cell morphology and pigment composition. Bot Acta 105:161-167

Fahnenstiel GL, Carrick HJ, Iturriaga R (1991) Physiological characteristics and food-web dynamics of Synechococcus in Lakes Huron and Michigan. Limnol Oceanogr 36: 219-234

Gifford DJ (1991) The protozoan-metazoan trophic link in pelagic ecosystems. J Protozool 38:81-86

Gladu PK, Patterson GW, Wikfors GH, Chitwood DJ, Lusby WR (1990) The occurrence of brassicasterol and epibrassicasterol in the chromophycota. Comp Biochem Physiol B 97:491-494

Goad LJ (1981) Sterol biosynthesis and metabolism in marine invertebrates. Pure Appl Chem 51:837-852

Goad LJ, Holz GG Jr, Beach DH (1983) Identification of (24S)24-methylcholesta-5, 22-dien-3 $\beta$-ol as the major sterol of a marine cryptophyte and a marine prymnesiophyte. Phytochemistry 22:475-476

Greenberg AE, Trussell RR, Clesceri LS (1985) Standard methods for the examination of water and wastewater. American Public Health Association, Washington, DC

Guillard RR (1975) Cultures of phytoplankton for feeding of marine invertebrates. In: Smith WL, Chanley MH (eds) Culture of marine invertebrate animals. Plenum Press, New York, p 26-60

Hadas O, Berman T (1998) Seasonal abundance and vertical distribution of protozoa (flagellates, ciliates) and bacteria in Lake Kinneret, Israel. Aquat Microb Ecol 14:161-170

Harvey HR, McManus GB (1991) Marine ciliates as a widespread source of tetrahymanol and hopan-3 $\beta$-ol in sediments. Geochim Cosmochim Acta 55:3387-3390

Harvey HR, Ederington MC, McManus GB (1997) Lipid composition of the marine ciliates Pleuronema sp. and Fabrea salina: shifts in response to changes in diets. J Eukaryot Microbiol 44:189-193

Hillebrand H, Dürselen CD, Kirschtel D, Pollingher U, Zohary $\mathrm{T}$ (1999) Biovolume calculation for pelagic and benthic microalgae. J Phycol 35:403-424

Jack JD, Gilbert JJ (1993) Susceptibilities of different-sized ciliates to direct suppression by small and large cladocerans. Freshw Biol 29:19-29

Jürgens K (1994) Impact of Daphnia on planktonic microbial food webs - a review. Mar Microb Food Webs 8:295-324

Jürgens K, Skibbe O, Jappesen E (1999) Impact of metazooplankton on the composition and population dynamics of planktonic ciliates in a shallow, hypertrophic lake. Aquat Microb Ecol 17:61-75

Jüttner F, Leonhardt J, Möhren S (1983) Environmental factors affecting the formation of mesityloxid, dimethylallylic alcohol and other volatile compounds excreted by Anabaena cylindrica. J Gen Microbiol 129:407-412

Kaneshiro ES, Beischel LS, Merkel SJ, Rhoads DE (1979) The fatty acid composition of Paramecium aurelia cells and cilia: changes with culture age. J Protozool 26:147-158

Klein Breteler WCM, Schogt N, Baas M, Schouten S, Kraay GW (1999) Trophic upgrading of food quality by protozoans enhancing copepod growth: role of essential lipids. Mar Biol 135:191-198

Klein Breteler WCM, Koski M, Rampen S (2004) Role of essential lipids in copepod nutrition: no evidence for trophic upgrading of food quality by a marine ciliate. Mar
Ecol Prog Ser 274:199-208

Lampert W (1977a) Studies on the carbon balance of Daphnia pulex as related to environmental conditions. I. Methodological problems of the use of ${ }^{14} \mathrm{C}$ for the measurement of carbon assimilation. Arch Hydrobiol Suppl 48:287-309

Lampert W (1977b) Studies on the carbon balance of Daphnia pulex as related to environmental conditions. II. The dependence of carbon assimilation on animal size, temperature, food concentration and diet species. Arch Hydrobiol Suppl 48:310-335

Lampert W (1981) Inhibitory and toxic effects of blue-green algae on Daphnia. Int Rev Ges Hydrobiol 66:285-298

Lampert W (1991) The dynamics of Daphnia in a shallow lake. Verh Int Ver Limnol 24:795-798

Mallory FB, Gordon JT, Connor RL (1963) The isolation of a pentacyclic triterpenoid alcohol from a protozoan. J Am Chem Soc 85:1362-1363

Marchessault P, Mazumder A (1997) Grazer and nutrient impacts on epilimnetic ciliate communities. Limnol Oceanogr 42:893-900

Martin-Creuzburg D, Von Elert E (2004) Impact of 10 dietary sterols on growth and reproduction of Daphnia galeata. J Chem Ecol 30:483-500

Martin-Creuzburg D, Wacker A, Von Elert E (2005) Life history consequences of sterol availability in the aquatic keystone species Daphnia. Oecologia 144:362-372

Müller H (1989) The relative importance of different ciliate taxa in the pelagic food web of Lake Constance. Microb Ecol 18:261-273

Müller-Navarra DC (1995) Evidence that a highly unsaturated fatty acid limits Daphnia growth in nature. Arch Hydrobiol 132:297-307

Müller-Navarra DC, Brett M, Liston AM, Goldman CR (2000) A highly unsaturated fatty acid predicts carbon transfer between primary producers and consumers. Nature 403: $74-77$

Pace ML (1982) Planktonic ciliates: their distribution, abundance, and relationship to microbial resources in a monomictic lake. Can J Fish Aquat Sci 39:1106-1116

Pace ML, Funke E (1991) Regulation of planktonic microbial communities by nutrients and herbivores. Ecology 72 : 904-914

Pace ML, Orcutt JD (1981) The relative importance of protozoans, rotifers, and crustaceans in a planktonic community. Limnol Oceanogr 26:822-830

Pernthaler J, Šimek K, Sattler B, Schwarzenbacher A, Bobkova J, Psenner R (1996) Short-term changes of protozoan control on autotrophic picoplankton in an oligomesotrophic lake. J Plankton Res 18:443-462

Pomeroy LR, Wiebe WJ (1988) Energetics of microbial food webs. Hydrobiologia 159:7-18

Porter KG, Pace ML, Battey JF (1979) Ciliate protozoans as links in freshwater planktonic food chains. Nature 277 : 563-565

Porter KG, Sherr EB, Sherr BF, Pace ML, Sanders RW (1985) Protozoa in planktonic food webs. J Protozool 32:409-415

Raederstorff D, Rohmer M (1988) Polyterpenoids as cholesterol and tetrahymanol surrogates in the ciliate Tetrahymena pyriformis. Biochim Biophys Acta 960:190-199

Ravet JL, Brett MT, Müller-Navarra DC (2003) A test of the role of polyunsaturated fatty acids in phytoplankton food quality for Daphnia using liposome supplementation. Limnol Oceanogr 48:1938-1947

Sanders RW, Porter KG, Bennett SJ, DeBiase AE (1989) Seasonal patterns of bacterivory by flagellates, ciliates, rotifers, and cladocerans in a freshwater planktonic com- 
munity. Limnol Oceanogr 34:673-687

Sanders RW, Williamson CE, Stutzman PL, Moeller RE, Goulden CE, Aoki-Goldsmith R (1996) Reproductive success of 'herbivorous' zooplankton fed algal and nonalgal food resources. Limnol Oceanogr 41:1295-1305

Sherr EB, Sherr BF, Berman T, Hadas O (1991) High abundance of picoplankton-ingesting ciliates during late fall in Lake Kinneret 1991. J Plankton Res 13:789-799

Šimek K, Bobkova J, Macek M, Nedoma J, Psenner R (1995) Ciliate grazing on picoplankton in a eutrophic reservoir during the summer phytoplankton maximum: a study at the species and community level. Limnol Oceanogr 40: 1077-1090

Šimek K, Macek M, Pernthaler J, Straškrabová V, Psenner R (1996) Can freshwater ciliates survive on a diet of picoplankton? J Plankton Res 18:597-613

Sterner RW, Schulz KL (1998) Zooplankton nutrition: recent progress and a reality check. Aquat Ecol 32:261-279

Stoecker DK, Capuzzo JM (1990) Predation on Protozoa: its importance to zooplankton. J Plankton Res 12:891-908

Sul D, Erwin JA (1997) The membrane lipids of the marine ciliated protozoan Parauronema acutum. Biochim Biophys Acta 1345:162-171

Sul D, Kaneshiro ES, Jayasimhulu K, Erwin JA (2000) Neutral lipids, their fatty acids, and the sterols of the marine ciliated protozoon, Parauronema acutum. J Eukaryot Microbiol 47:373-378

Tang KW, Taal M (2005) Trophic modification of food quality by heterotrophic protists: species-specific effects on copepod egg production and egg hatching. J Exp Mar Biol Ecol 318:85-98

Ten Haven HL, Rohmer M, Rullkötter J, Bisseret P (1989) Tetrahymanol, the most likely precursor of gammacerane, occurs ubiquitously in marine sediments. Geochim Cosmochim Acta 53:3073-3079

Tezuka Y (1974) An experimental study on the food chain among bacteria, Paramecium and Daphnia. Int Rev Ges Hydrobiol 59:31-37

Venkatesan MI (1989) Tetrahymanol: its widespread occur-

Editorial responsibility: Fereidoun Rassoulzadegan, Villefranche-sur-Mer, France rence and geochemical significance. Geochim Cosmochim Acta 53:3095-3101

Von Elert E (2002) Determination of limiting polyunsaturated fatty acids in Daphnia galeata using a new method to enrich food algae with single fatty acids. Limnol Oceanogr 47:1764-1773

Von Elert E, Stampfl P (2000) Food quality for Eudiaptomus gracilis: the importance of particular highly unsaturated fatty acids. Freshw Biol 45:189-200

Von Elert E, Wolffrom T (2001) Supplementation of cyanobacterial food with polyunsaturated fatty acids does not improve growth of Daphnia. Limnol Oceanogr 46: 1552-1558

Von Elert E, Martin-Creuzburg D, Le Coz JR (2003) Absence of sterols constrains carbon transfer between cyanobacteria and a freshwater herbivore (Daphnia galeata). Proc R Soc Lond B 270:1209-1214

Wacker A, Von Elert E (2001) Polyunsaturated fatty acids: evidence for non-substitutable biochemical resources in Daphnia galeata. Ecology 82:2507-2520

Weers PMM, Siewertsen K, Gulati RD (1997) Is the fatty acid composition of Daphnia galeata determined by the fatty acid composition of the ingested diet? Freshw Biol 38: 731-738

Weisse T (1993) Dynamics of autotrophic picoplankton in marine and freshwater ecosystems. In: Jones JG (ed) Advances in microbial ecology, Vol 13. Plenum Press, New York, p 327-370

Weisse T, Müller H, Pinto-Coelho RM, Schweizer A, Springmann D, Baldringer G (1990) Response of the microbial loop to the phytoplankton spring bloom in a large prealpine lake. Limnol Oceanogr 35:781-794

Wickham SA, Gilbert JJ, Berninger UG (1993) Effects of rotifers and ciliates on the growth and survival of Daphnia. J Plankton Res 15:317-334

Zöllner E, Santer B, Boersma M, Hoppe HG, Jürgens K (2003) Cascading predation effects of Daphnia and copepods on microbial food web components. Freshw Biol 48: 2174-2193

Submitted: July 7, 2005; Accepted: October 19, 2005

Proofs received from author(s): December 14, 2005 